\title{
Ekspresi Keberagamaan Di Era Revolusi Industri 4.0; Desrupsi Ide, Pilihan Sikap, dan Kontestasi Ideologi Keberagamaan di Indonesia
}

\section{Sulanam}

Universitas Islam Negeri (UIN) Sunan Ampel Surabaya Jl. Ahmad Yani No.117, Jemur Wonosari, Kec. Wonocolo, Kota SBY, Jawa Timur e-mail:sulanam@uinsby.ac.id

\begin{tabular}{|c|c|c|}
\hline Diterima: & Revisi: & Disetujui: \\
10 Januari 2020 & 20 Februari 2020 & 15 Maret 2020 \\
\hline DOI: & DOI 10.32332/tarbawiyah.v4i1.1825 \\
\hline
\end{tabular}

\begin{abstract}
This paper will explore four important issues related to religious expression in Indonesia, especially in the era - which some call it the fourth industrial revolution. An era, one of which features is, people are digitally connected and are very dependent on internet access. These four things are: first, the dynamics of religious expression after the reformation, as a marker of fundamental changes in social attitudes; from canalization to unlimited democracy. Second, desruption of religious ideas. Third, a new way of choosing religious attitudes. Finally, the impact of religious political deconstellation and ideological order in Indonesia. Methodologically, this writing approach will use the anthropological paradigm; in order to be able to see the phenomenon of attitudes that appear and manifest in the contemporary era, and phenomenology as a reading device to assess the posture of consciousness that forms the expression of diversity. In conclusion, this paper, does not want to judge or analyze which religious expressions are the most right and wrong in the era of the industrial revolution 4.0. Instead, this paper simply wants to describe what happened after the technological progress of 'improving' and 'damaging' the religious values understood/expressed by Muslims in Indonesia.
\end{abstract}

Keyword Expression of Religion, Industrial Revolution 4.0, and Religious Ideology in Indonesia

Abstrak Tulisan ini akan mengeksplorasi empat hal penting yang berhubungan dengan ekspresi keberagamaan di Indonesia, khususnya di era - yang sebagian kalangan menyebutnya revolusi industri 4.0 (the fourth industrial). Sebuah era, yang salah satu fiturnya ialah, masyarakat terkoneksi secara digital dan 
sangat bergantung pada akses internet. Empat hal tersebut adalah: pertama, dinamika ekspresi keberagamaan pasca reformasi, sebagai penanda perubahan sikap sosial secara fundamental; dari terkanalisasi ke demokrasi tanpa batas. Kedua, desrupsi ide keberagamaan. Ketiga, cara baru pilihan sikap keberagamaan. Terakhir, dampak dekonstelasi politik keberagamaan dan percaturan ideologis di Indonesia. Secara metodik, pendekatan tulisan ini akan menggunakan paradigma antropologis; agar bisa melihat fenomena sikap yang tampak dan mengejawantah di era kontemporer, serta fenomeno-logisme sebagai perangkat baca untuk menilai postur kesadaran yang membentuk ekspresi keberagamaan tersebut. Kesimpulannya, tulisan ini, tidak ingin menilai atau menganalisis mana ekspresi keagamaan yang paling benar dan salah di era revolusi industri 4.0. Sebaliknya, tulisan ini sekedar ingin menggambarkan apa yang terjadi pasca kemajuan tekhnologi 'memperbaiki' dan 'merusak' nilai-nilai keberagamaan yang dipahami/diekspresikan oleh umat Islam di Indonesia.

Kata Kunci Ekspresi Keberagamaan, Revolusi Industri 4.0, dan Ideologi Keberagamaan di Indonesia

\section{A. Pendahuluan}

Logos 'revolusi industri 4.0" hadir sebagai bentuk dari penamaan era dan zaman yang hari ini dihadapi oleh masyarakat dunia. Penamaan ini tidak jauh berbeda dengan kata klasik, modern, dan kontemporer, hanya berbeda dari sumber (arbiter) penamaannya. Kata 'revolusi industri 4.0' berasal dari narasi pemanfaatan ilmu pengetahuan, tekhnologi informasi, dan perubahan mindset pemahaman akan kondisi ekonomi, bisnis, dan manajerialisme di dalamnya. ${ }^{1}$ Sedangkan klasik, modern, dan kontemporer, berasal dari paradigma periodic dan geneologis dari perjalanan sejarah manusia sebagai makhluk sosial. Tidak selalu berasal dari perubahan ilmu pengetahuan ataupun pemahaman masyarakat akan kondisi tersebut. Dalam bahasa yang lebih sederhana, penamaan masa ruang dan waktu menjadi sumber utama logos kedua. Pasca penimbulan dan penamaan, maka akan selalu muncul fitur atau karakteristik yang dihasilkan. Mc Afee dan Howard, dalam Oosthuizen, menyatakan bahwa ada tiga kesimpulan umum

${ }^{1}$ Roland Berger, "Industry 4.0, The New Industrial Revolution: How Europe Will Succeed, Munich, diakses melalui http://www.rolandberger.com/media/pdf/pada 12 Juni 2017. 
terkait revolusi industri 4.0 ini; pertama, privatisasi diri sendiri dalam kehidupan dan progresifitas tekhnologi informasi. Kedua, adanya keuntungan terhadap penggunaan tekhnologi informasi di kehdipan sosial; dan ketiga, ada juga potensi buruk dari proses digitalisasi yang dilakukan oleh seseorang atau dunia usaha terhadap aktivitas yang dikerjakan. ${ }^{2}$

Robert Philips menyederhanakan kondisi ini dengan menganggap bahwa revolusi industri 4.0 bermakna sebuah kondisi dimana manusia terinteraksi dan terintegrasi pada model kehidupan yang serba terdigitalisasi, terbantukan oleh tekhnologi dan mesin, sekaligus, kekuatan ilmu pengetahuan dalam mengatur pola hidup masyarakat secara efektif dan efesien. ${ }^{3}$ Sama halnya dengan sebelumnya, Bo Xing dan T Marwala memberikan tiga karakteristik revolusi industri 4.0 ; pertama, digitalisasi dan integrasi mata rantai kehidupan (organisasi) baik secara vertical ataupun horizontal. Kedua, digitalisasi promosi dan layanan produk. Ketiga, Bisnis berbasis digital dan akses terhadap pelanggan. ${ }^{4}$ Dari pelbagai definisi di atas, sejatinya, ada kesamaan penekanan dalam pendefinisian terkait 'logos' Revolusi Industri 4.0, yakni; digitalisasi dan komputerisasi data, aktivitas, program, dan sisi lain yang menjadi bagian dari kehidupan manusia; apakah itu dalam skala yang kecil (organisasi atau perusahaan) atau skala luas (administrasi pemerintahan ataupun sosial kemasyarakatan).

Oleh karena cakupan yang cukup luas. Tidak bisa dipungkiri hal ini juga akan mempengaruhi pola kehidupan masyarakat. The World Economic Forum mengidentifikasi ada enam software dan megatrends kehidupan sosial yang bisa menjadi penanda entitas revolusi industri 4.0 ini, yakni; manusia dan internet, komputerisasi-komunikasi, internet of The Things, Artificial Intelligence (IA) and Big Data, sharing dan kepercayaan yang didestribusikan, dan digitalisasi semua persoalan. Lorenz menambahkan kalau ada 10 dampak daripada

2 Jacobus Oosthuizen "The Determinant of Fourth Industrial Revolution Leadership Dexterity; a Poposed Framework for 4IR-Inteligence and Subsequest 4IR Leadership Development" dalam Proceeding of International Conference of Resources Management, Milpark Buiness School, h. 30

3 Ibid, h. 32

4 Bo Xing \& T Marwala "Implication of the Fourth Industrial Age on Higher Education" dalam Proceedings of the International Joint Conference on Neural Networks, BC, Canada, Maret 2017, h. 12. 
revolusi industri 4.0. Yaitu; big-data akan menentukan kualitas, robotassisted production (mengganti manusia dengan robot untuk melakukan produksi), produk yang diantarkan sendiri, batasan produksi, networking, predictive maintenance (prediksi yang berkesinambungan), mesin sebagai alat layanan, produksi mandiri, manufacturing, dan orientasi pada kerja, kesinambungan, dan layanan optimal. ${ }^{5}$

Penulis pun berkeyakinan, perubahan cara pandang membangun atau mngelola industri ini pula, juga berdampak pada cara orang memahami agama, mengekspresikan, serta mengkomunikasikan kepada orang lain. Di era sebelumnya, orang memahami agama, bisa saja dengan model sangat sederhan, yakni; melihat apa yang mengejawantah di sekitar mereka. Memandang apa yang ditauladankan oleh tokoh agama, ataupun mendatangi lembagalembaga keagamaan untuk belajar agama. Namun hari ini, di era yang sudah terdigitalisasi, sebagaimana karateristik di atas, agama sudah masuk ke ruang publik tanpa batasan apapun. Agama hadir pada diskursus yang tergitalisasi. Agama hadir sebagai pilihan yang dikomunikasikan dengan cara-cara yang lebih mudah dibandingkan sebelumnya. Agama pun 'bisa menjadi alat' untuk menghasilkan keuntungan ekonomi, melalui pemanfataan pendekatan karakter masyarakat di era revolusi industri 4.0.

Secara cultural, Terri Anne Tao menyatakan bahwa Revolusi Industri 4.0 sudah merubah budaya pengelolaan negara, memiliki dampak pada pandangan politik masyarakatnya, hilangnya nilai-nilai ruang pivat, kebebasan untuk mengutarakan apapun (freedom of speech), dan kuatnya individualisme. ${ }^{6}$ Dari pandangan ini pula, maka secara antropologis, di era sekarang, semua orang bisa melihat bagaimana agama diekspresikan melalui media sosial yang sejatinya dimiliki seseorang secara personal. Penyebaran pemahaman keagamaan melalui alat digital non-mainstream, seperti Youtube, Vidio, dan aplikasi lainnya. Serta dialog-dialog keagamaan yang terjadi di ruang maya, tanpa harus bertatapan langsung kepada pemegang otoritas keagamanaan.

Berdasarkan pada fenomena dialektis inilah, tulisan ini penulis hadirkan dengan sistematika sebagaimana berikut; pertama, antropologi ekspresi keagamaan di Indonesia, pasca reformasi sampai era

\footnotetext{
5 Ibid, h. 23

6 Ibid, h. 24
}

Tarbawiyah: Jurnal Ilmiah Pendidikan :: Volume 04; Nomor 1, Juni 2020 
Revolusi Industri 4.0. Kedua, desrupsi dan trend simbolik yang ditampilkan dalam bentuk komunikasi keberagamaan. Ketiga, reduksi pemahaman masyarakat terhadap symbol dan ekspresi keagamaan di era Revolusi Industri 4.0. Keempat, kontestasi ideologis dan ancaman identitas kultural sebagai dampak dari Revolusi Industri 4.0.

\section{B. Anrtropologi Ekspresi Keagamaan di Indonesia}

Salah satu keunikan bangsa Indonesia ialah negara 'selalu' hadir untuk tetap memproteksi bahwa agama-agama yang berkembang di Indonesia memiliki hak yang sama; apakah itu diyakini, diekspresikan dan disebarkan sesuai ajaran agama mereka masing-masing. Karena, setelah menjadi Indonesia, ideology bangsa Indonesia bernama Pancasila merupakan pengejawantahan dari integralisme agamaagama yang tumbuh dan berkembang di Indonesia, termauk di dalamnya keyakinan asali yang dimilki masyarakat. Tercatat, pemerintah mengakui ada enam agama dan ratusan paham keyakinan yang berkembang selama ini. Dan dari semua itu, Indonesia masih menjadi negara yang rukun dan guyup, kendati tekadang ada konflikkonflik sosial, yang disulut oleh faktor selain agama atau didominasipenulis katakan - karena faktor ekonomi dan politik semata. Sedangkan konflik keberagamaan, dihasilkan sebagai alat penggerak masyarakat dan kekuatan dogmatis untuk melakukan tindakan (anarkhis) kepada orang lain.

Secara historis, agama Islam-yang hari ini menjadi agama mayoritas di Indonesia sebanyak 87 \% - merupakanagama yang hadir paling mutaakhir, dibandingkan Kristen, Hindu, Budha, dan Konghuchu. Dominasi agama Islam di dalam masyarakat Indonesiademikian halnya dengan agama lainnya - tidak berasal bersumber dari 'peperangan'. Sehingga, keberadaan agama sejatinya tersublimasi dalam bentuk cross-cultural dan amalgamasi sesuai dengan pilihan dan pilahan hati masyarakat Indonesia kala itu. Hal inipulalah yang kemudian menjadikan umat beragama di Indoensia guyup dan rukun antara satu agama dan lainnya. Perubahan dan 'pemberontakan' yang terekpresikan dari ajaran dan nilai-nilai keagamaan di Indonesia, baru dimulai pasca kemerdekaan. Kelompok-kelompok Islam, waktu itu, mengharapkan agar Indonesia dirubah dari asas Tunggal Pancasil ke negara yang berlandaskan agama paling mayor, yakni Islam. Ekspresi keagamaan yang menjadi sikap politik ini, kemudian, hidup hingga hari ini. Penulis menyebutnya sebagai "living conflict" antara kelompok 
(Islam) dan sebagian agama lain, atau kelompok 'nasiolalis' yang masih menjaga nilai-nilai kebersamaan, persatuan, dan keguyuban di masa lampau; dimasa perjuangan untuk memperjuangkan kemerdekaan Indonesia.

Ekspresi keagamaan bernuansa politik ini, pada masa-masa tertentu, acapkali merusak ekspresi keagamaan lainnya. Semisal, ekspresi peribadahan, keadatan, dan nilai-nilai lain yang diyakini oleh agama selain Islam. Oleh sebab itulah, tidak salah apabila concern hampir semua Indonesianis, seperti Greg Fealy 7 , Martin Van Bruinessen, ${ }^{8}$ Robert W. Hefner, ${ }^{9}$ dan lainnya, mendahulukan membaca ekspresi keberagamaan umat Islam daripada umat lain yang menyimpan dan menjaga tradisi-ajaran keagamaan mereka pada ruang dan tempat yang lebih eksklusif. Ekpresi-ekpresi keagamaan selain Islam, hanya bisa dilihat sangat tampak di beberapa provinsi, dimana mereka menjadi mayoritas di daerah mereka. Misalnya, ekpresi keberagamaan Kristen (Katolik-Protestan) di Indonesia Timur, khususnya Provinsi. Demikian halnya masyarakat Hindu-Budha di Bali. Di beberapa daerah semisal di Jawa, Kalimantan, dan Aceh, kala umat Islam mendominasi, maka ekspresi keberagamaan di daerah tersebut tidak tampak dan lebih condong tertutup. Kendati dalam kehidupan

7 Adapun terkait institusionalisasi pemikiran fundamentalisme dan modelmodel transmisi keilmuan kelompok transnasional (baca; salafi, wahabi, dan aliran lainnya) bisa dikaji dalam Farish A Noor, Yogindar Sikand, dan Martin Van Bruinessen, ed, The Madrasa in Asia; Political Activism and Transnational Linkage (Amsterdam; Amsterdam University Press, 2008). Lihat juga Charlene Tan, Islamic Education and Indoctrination; The Case of Indonesia (New York; Routledge, 2011). Bandingkan juga dengan karya sebelumnya, Greg Fealy dan Anthony Bubalo, Jejak Kafilah, terj. Akh. Muzakki (Bandung; Mizan, 2004). Dari semua buku yang penulis cermati di atas, harus diakui, bahwa memang menghalau gerakan-gerakan transnasional di Indonesia sudah tidak semudah dikala politik kanalisasi pemikiran Islam dan ideology nasionalisme dilakukan oleh Orde Lama dan Orde Baru. Sebagaimana diungkapkan oleh Greg Fealy and Anthony Bubalo, dalam rekomendasi risertnya, pemerintah dan para aktivis pendidikan harus melihat peran ganda demokratisasi yang dijalankan di Indonesia. Tanpa seperti itu, masyarakat Indonesia akan terjerumus pada quasi-democracy dimana masyarakat tidak mendapatkan nilai-nilai subtantif daripada apa makna demokrasi tersebut.

8 Martin Van Bruisennen, "Tradisional and Islamist Pesantrens in Contemporary Indonesia" dalam Fasrish A Noor edt. Madrasa in Asia; Political Activism and Transnational Linkages (Amsterdam; Amsterdam University Press, 2008), h. 217-218

9 Robert W. Hefner, "Islamic School, Social Movement, and Democracy in Indonesia", dalam Robert W. Hefner edit, Making Modern islam Politic of Education in South Asia (USA: Hawai University Press, 2009), h. 58. 
sosial mereka sudah tidak membedakan agama apa yang dianut. Mereka berinteraksi sebagai masyarakat dan terus menerus menjunjung nilai-nilai kemajemukan yang ada di Indonesia.

Pada kesimpulannya, sebagaimana Survey Kerukunan Umat beragama di Indonesia, sisi keberagamaan di Indonesia - khususnya dalam lintas paham-paham keagamaan-tergolong baik.10 Masyarakat Indonesia mau dan mampu untuk mengekpresikan nilai-nilai agama sebagai proporsinya. Sekali lagi, sisi 'negatif' ekspresi dari redusksi paham keagamaan menajdi bermasalah apabila dibumbui dengan muatan-muatan kepentingan elit politik, kecemburuan ekonomi dan sosial di daerah atau lingkungan tersebut. Idrus al-Hamid mengatakan bahwa pasca menguatnya politik Identitas di Indonesia di Era Reformasi, hingga menumbuhkan banyak daerah yang menginginkan agama mayoritas masuk menjadi penentu kebijakan dan regulasi di daerah, akhirnya menjadikan daerah yang lain pun ingin menrunya. Dia menceritakan bahwa konflik-konflik keagamaan di Jayapura, awalnya, hanya persoalan etnisitas antara pendatang dan orang asli Papua. Namun hari ini, persoalan purba itu bertambah menjadi pertimbangan keberagamaan. Jadi, masyarakat Papua sendiri yang memeluk agama selain agama Asli, mulai mendapatkan perlakuan yang kurang baik. Setelah ditelisik, persoalan utamanya adalah deskriminasi keagamaan yang terjadi di Jawa sebagai acuan melalui Peraturan Daerah yang dibumbui dengan nilai-nilai keagamaan. ${ }^{11}$ Yang menarik memang,

10 Ahmad Syafi'i Ma'arif, Politik Identitas dan Masa Depan Pluralisme Kita, (Jakarta; Democracy Project, 2012), h. 18

11 Idrus al Hamid, "Islam Politik di Papua; Resistensi dan Tantangan Membangun Pedamaian" dalam Jurnal Millah Vol XII, No 02 Tahun 2013, h. 443. Dan bisa juga dipandang bahwa Interpretasi ajaran keislaman berdasarkan pada representasi lokal dalam tradisi Islamic Studies diungkapkan oleh Dale F. Eickelman, "The Study of Islam in Local Context" dalam Richard C. Martin Contribution to Asian Studies, vol. xvii Tahun 1982. H. 1. Menurutnya, cara pandang Islam terbangun dari dua model; Islams dan islams. Islam dengan I (besar) bermakna islam sebagai penuntun dan petunjuk untuk ekspresi lokal. Namun sebaliknya, islmas (dengan i kecil) bermakna bahwa ekspresi keislaman terkait dengan nilai-nilai lokal. Dalam konteks lain, Kim Knott dengan teori spatialnya menyatakan bahwa ajaran islam bisa dibatasi melalui bagaimana ruang, waktu, dan ekspresi masyarakat pada bentuk yang eksklusif. (Lihat: Kim Knot, "Spatial Theory and Method for Study of Religion" dalam The Fenmish Study for the Study of religion, (Temenos, Volume 41. No 2, 2005), h. 155. Atau bisa juga dipresentasikan dalam kontestasi ekspresi simbolik seperti yang dikatkan oleh Akh Muzakki "Fenomena Premanisme Kelompok Keberagamaan dalam perspektif Studi Islam (Makalah seminar "Islam dan Premanisme Kelompok Keberagamaan" oleh Pusat 
selain dari pelbagai ekspresi umat yang beragama Islam, persoalanpersoalan agama lain di Indonesia cenderung minim. Kelompok agama minoritas seakan sangat menyadari bahwa mereka harus tetap menjaga privasi keberagamaan mereka, serta tidak banyak menuntut dan mengekpresikan di ruang publik, laiknya kelompok mayoritas. Hal yang paling tampak hanyalah dikala perayaan-perayaan hari besar umat beragama tersebut. Kendati, fenomena ini tidak bisa dilepaskan dari akomodasi pemerintah untuk memberikan ruang publik bagi agama minoritas tersebut. Dalam bahasa yang lebih sederhana, publikasi dan pengejawantahan ajaran-ajaran keagamaan kelompok minoritas hanya bersinggungan dengan relasi manusia dengan manusia, tidak seperti Islam yang berhadap-hadapan secara politik dengan komposisi nilai Pancasila sebagai ideology yang menyatukan perbedaan yang ada di Indonesia.

\section{Desrupsi Ide Keberagamaan di Indonesia}

Senyana dengan yang sudah disebutkan, ekspresi yang minim bisa dilihat dari agama lain, menjadikan concern tulisan ini akan lebih banyak pada narasa ekspresi keislaman. Sebab, diakui atau tidak, ekspresi keislaman akan menjadi penentu keutuhan Negara Kesaturan Republik Indonesia. Penentu akankah Indonesia akan menjadi negara yang mampu mengakomodasi perbedaan-perbedaan yang terjadi secara takdiri; tanpa harus diminta. Umat Islam di Indonesia-yang mayor ini-akan melindungi kelompok minor yang secara senyap meyakini dan menjalankan ajaran yang ada. Selain faktor sosiologis tersebut, ada juga pertarungan global yang sedang menjangkiti umat Islam itu sendiri. Ada pemikiran yang berlawanan dengan kebudayaan paling digdaya bernama "western" atau "Barat". Padahal, semua orang paham bahwa Islam bukanlah sebuah teritori, melainkan agama, sedangkan kultus 'Barat' bukanlah agama melainkan sebatas peradaban manusia yang hidup di Barat umat Islam mendominasi negara tersebut.

Kalau juga melihat sisi historis, persinggungan agama (baca; Islam) dan negara adalah ide klasik yang dibumbui oleh pertempuran di Indonesia. Meski, ide mendirikan negara Islam — kala itu - lebih disebabkan faktor pemahaman individu dan keyakinan akan paham

Pengembangan Intelektual (P2I) Program Pascasarjana IAIN Sunan Ampel, di Gedung SAC, IAIN Sunan Ampel, Surabaya, 26 September 2012. 
keislaman. Sosok M. Natsir, M. Yasin, Agus Salim, dan beberapa tokoh Islam lainnya sedikit berbeda konsep kenegaraan dengan Pancasila dan Nation State yang ditawarkan oleh Soekarno. Namun, sejarah mencatat, perdebatan ide tersebut bukan dikarekan para kelompok Islamist didukung oleh kekuatan politik di luar Indonesia. Para kelompok Islamist tersebut memang paham dan yakin bahwa konsep negara agama (Islam) adalah pilihan rasional karena umat Islam paling banyak. Jadi, pasca adanya penolakan yang dibumbui debat argumentatif dari beberapa orang Islam (baca; KH. Hasyim Asy'ari dan tokoh lainnya), kelompok penyokong negara Islam inipun menerimanya secara seksama. Mereka tidak memaksakan atau menarik diri dari konsensus tersebut. Walaupun ide untuk mendirikan Negara Islam Indonesia masih terus disuarakan.

Ekpresi dan kontestasi ideologis agama dan negara mulai hilang pasca Soeharto memimpin. Soeharto melakukan kanalisasi dari seluruh kehidupan masyarakat Indonesia; mulai dari penyederhanaan partai politik, otoritas keagamaan, dan skala penguatan ekonomi. Ide dan ekspresi keagamaan pun sangat terbatas. Pemerintah hadir dengan sangat dominan. Kelompok-kelompok Islamis yang berserikat untuk melawan kekuasaan rezim dideportasi dan terus menerus diawasi. Tidak hanya itu, organisasi keagamaan yang ingin menyelenggarakan kegiatan keagamaan harus mendapatkan izin dari pemerintah. Terlepas dari dominasi tersebut, harus diakui, kondisi Indonesia terlihat lebih guyup dan rukun dibandingkan sebelumnya. Pemerintah hadir dan mengaplikasikan sistem politik Pancasila sebagai identitas orang Indonesia, dalam bentuk tafsir pemerintah orde baru. Orang Indonesia — seakan - kehilangan makna kemajemukan dari sisi ide dan pemikiran keagamaan. Sebagaimana diketahui, tafsir keagamaan Islam di Indonesia diserahkan pemerintah pada Majelis Ulama' Indonesia (MUI), Ikatan Cendikiawan Muslim Indonesia (ICMI), dan kelompok lain yang dibuat sendiri oleh pemerintah sebagai kanal keagamaan. ${ }^{12}$

Pada porsi dan posisi masyarakat yang dikekang, informasi terkait agama pun sepi dari ruang publik. Hal ini juga didukung secara global. Kala itu, kondisi dunia masih berada pada Revolusi Industri 3.0;

12 Husniyatus Salamah "Politic of Cirizenship; Shape of identities, education and critical media literacy" Paper Seminar Internasional Pendidikan Islam di UM Malang Pada Desember 2016; (tidak dipublikasikan). 
dimana computer dan produk digital menjadi penentu gerak dan ekspresi kemasyarakatan. Produk digital dan konektivitas masyarakat terhadap informasi dan ide keagamaan pun dibuat pemerintah. Pemerintah Orde Baru mensensor dan menfilter apa yang perlu atau tidak perlu disampaikan kepada masyarakat. Jadi, pada era Soeharto ide dan ekspresi keagamaan di Indonesia tidaklah banyak, dan tidak pula 'dipengaruhi' oleh pemahaman transnasional, semisal kelompok jihadis dan politik Islam (baca; ikhwanul muslimin). Secara organisatoris pun hanya ada Nahdlatul Ulama', Muhammadiyah, dan organisasi bentukan pemerintah yang diperkenankan pemerintah untuk menjalankan aktivitas sosial-keagamaan di Indonesia. Selain mereka pemerintah melakukan pemantauan yang sangat ketat, agar tidak mempengaruhi kekuasaan dan kondisi sosial di masyarakat.

Pasca reformasi, kondisi Indonesia berubah total. ide keagamaan (Islam) tidak lagi menjadi milik pemerintah dan organisasi keagamaan yang ada dan berkembang di Indonesia. Ide keagamaan muncul dari banyak arah, termasuk dari kelompok-kelompok jihadis yang sempat dideportasi oleh pemerintah. Pemerintah di era reformasi menjunjung tinggi kebebasan untuk mengekspresikan apapun yang diyakini dan dipahami di dalam agama mereka masing-masing. Kebebasan ini pula menjadikan perdebatan akan ekspresi keagamaan tidak didominasi antar atau lintas agama semata, melainkan juga internal umat beragama. Pada era reformasi ide dan ekspresi keislaman terbagi menjadi tiga model; ada yang fundamentalis - seperti pemikiran kelompok radikal di konteks global, ada yang liberal — seperti para pemikir Islam yang hidup di negara demokrasi, ada juga yang moderat - pemikir Islam yang hadir sebagai kelompok yang berfikir dan mengekpresikan agama Islam secara subtantif, bukan pemikiran politik, sosiologis, dan sistem ekonomi.

Ide fundamentalisme akan menampilkan beberapa fitur ekspresi keberagamaan (khususnya di Islam) adalah mereka menginginkan ajaran-ajaran keislaman yang normatif, tekstualis, dan formatif secara sistem politik ${ }^{13}$. Selain itu, ide-ide ini, terkadang, juga diekspresikan secara berlebihan hingga menimbulkan sikap eksklusif, radikal, dan anarkhis. Contoh kongkrit kelompok-kelompok yang memiliki pandangan kemudian berekspresi sebagaimana dimaksud adalah;

13 Yudi Latief, Geneologi Íntelegensia; Pengetahuan dan Kekuasaan Intelegensia MusIm (Jakarta; Kencana Gramedia Group, 2013) 
Front Pembela Islam, Jemaah Islamiyah, Forum Umat Islam, dan beberapa organisasi kepemudaan Islam yang berkembang pada masa reformasi dijalankan di Indonesia. ${ }^{14}$ Ide, ekspresi, dan sikap yang demikian bisa dilihat dalam skala makro sebagai bentuk respon terhadap perlakuan imprealisme Barat terhadap negara-negara Islam di pilahan dunia. Artinya, ide dan sikap eksklusif keberagamaan Islam terhadap non-Muslim di Indonesia tidak hadir sebagai wujud daripada ajaran keislaman yang ada, tumbuh, dan berkembang dalam bingkai dan alur keislaman yang sudah ada sebelumnya.

Kebalikannya, adapula ekspresi ide pemikiran dan sikap keberagamaan (Islam) yang hadir sebagai lawan daripada kelompok fundamentalis, yakni mereka yang dikategorikan kelompok Liberal secara pemikiran dan progresif-leberatif secara pemikiran. Fitur kelompok ini, dalam pandangan penulis, lebih mengedepankan pandangan bahwa agama adalah ruang privat yang tidak boleh diintervensi oleh negara. Agama harus hadir 'sebatas' nilai yang diyaniki secara individu, bukan kolektif. Agama juga harus diberikan ruang sebebas-bebasnya diekspresikan di ruang publik. Mereka pun beranggapan bahwa agama atau keyakinan individu atau kelompok 'tidak boleh diarahkan' oleh siapapun, bahkan dikala dia harus mengganti keyakinan. Kendati sangat ekstrim, namun pemikiran ini tidak banyak mendapatkan tempat di Indonesia. Ide ini hanya sebatas 'diskursi' yang berjalan secara ilmiah, tidak banyak mempengaruhi ekspresi dan sikap di dunia sosial, ekonomi, dan politik.

Diantara dua kelompok pemikiran ini, ada ide moderatisme sebagai bentuk penengah. Ide inilah yang banyak diikuti dan diekspresikan oleh silent majority yang ada di masyarakat Indonesia. Sikap moderat ini, penulis kira, tidak hanya dimiliki oleh umat Islam, melainkan juga agama lainnya. Pasalnya, agama Non-Islam merasakan pengahargaan yang setimpal dari kelompok Islam, sehingga dogmatism visionary atau missionary yang semestinya mereka juga ajarkan pada

14 Arie Setyaningrum Pamungkas, "The Dakwah Media in Post Soeharto Indonesia; From Politics Identity to popular culture; The Case of Ummi, (Phd Thesis Universitas Berlin 2015), 234, bandingkan dengan Syamsul Rizal, "Media and Islamism in Post New Order Indonesia; The Case of sabili", dalam Jurnal Studia Islamika Vol 12 No 3, Tahun 2005, (Jakarta; UIN Syarif Hidayatullah, 2005), h. 431; Lihat Juga Zifirdaus Adnan, "Ideological Conflict between the Indonesian Government and the Indonesian Muslim Radical" dalam Australian Folklore: a Yearly Journal of Folklore Studies; February 2017, (Australia; Australian Folklore, 2017), h. 26 
orang lain, disimpan sebagai bentuk penghormatan pada perbedaan yang bukan hak manusia di dalamnya. Kelompok moderat ini memiliki ciri toleran terhadap perbedaan, kesalehan dalam sikap sosial, dan menjauhkan diri dari sikap-sikap anarkhir. Mereka lebih mengutamakan dialog untuk menyelesaikan persoalan keagamaan yang berkembang di masyarakat. Kendati mereka toleran, bukan berarti mereka abai akan ajaran keagama, seperti yang disematkan kepada kelompok liberal. Mereka pada satu sisi masih menjalankan dan mengajarkan agama di ruang publik sebagai bentuk kewajiban (dakwah) kepada umat Islam. Tanpa harus mengusik agama lain. Mereka juga tidak melepaskan agama dari sistem dan nilai-nilai kenegaraan. Indonesia harus tetap menjalankan nilai keagamaan, tanpa harus merubah sistem demokrasi yang diyakini oleh para pendahulu sebagai ijtihad politik.

Tiga pilihan rasional, sikap, dan ekpresi keberagamaan di atas, di era yang disebut dengan revolusi industri 4.0 pun tidak jauh berbeda dari sebelumnya. Masyarakat yang sudah mulai terkoneksi dengan produk digital tanpa batasan tersebut bisa melihat apa bagaimana ekpresi keagamaan disampaikan dan ditampilkan secara lebih mudah. Ada yang melalui visualisasi seorang ulama' dalam mempraktekkan pemahaman yang dimiliki, tulisan yang disebarkan melalui laman media sosial, gagasan yang dikemas dalam bentuk tampilan gambar, dan lain sebagainya. ${ }^{15}$ Hal yang lebih serta sangat berbeda dengan sebelumnya, model-model ekspresi keagamaan yang hadir lebih seragam. Kelompok-kelompok fundamental bisa mengemas ideology 'radikal' mereka di balik laman diskursif "kataatan penuh terhadap hukum Allah". Disembunyikan dalam pemurnian akidah Tauhid. Sekaligus 'memecah' mana yang murni Islam, dan Islam yang terekspresi secara asimilatif di lingkungan masyarakat lainnya. ${ }^{16}$

Laman dan diskursi keyakinan individu di ruang publik yang merepresentasikan ajaran-ajaran Islam menjadi masyarakat Islam dan non-Muslim mendapatkan pemahaman yang tidak lagi mono-tafsir. Bahkan, fitur-fitur keislaman mulai kabur. Tidak jarang orang nonMuslim akhirnya anti-pati terhadap kebiasaan umat Islam yang

15 Siti Qomala Khayati, "Mengantisipsi Lawan Diskursif Islam-Indonesia; bingkai Baru Kelompok Radik menggerogoti Pancasila" dalam Proceeding Annual Confrence of Muslim Scholar, Surabaya 2018, h. 198

16 Merlyna Lim, "Radical Islamism in Indonesia and Its Middle Eastern Connection," dalam Meria Journal, Volume 15, Issue 2 June Tahun 2011, (tt, tt,), h. 34

Tarbawiyah: Jurnal Ilmiah Pendidikan :: Volume 04; Nomor 1, Juni 2020 
intoleran. Kendati, orang-orang non-Muslim tidak bisa memberikan banyak pengaruh pada umat Islam, sebab mereka adalah golongan minoritas. Jika mau melihat secara antropologis dan sosiologis bagaimana ekspresi keislaman di era digital, semua orang bisa merujuk pada kontestasi politik hingga perdebatan di lini masa hari ini. Tercatat, sebagaimana yang penulis ingat terkait ekspresi keislaman, di era digital ini, misalnya; Kasus Penistaan Agama yang dilakukan oleh Ahok, lalu dikapitalisasi menjadi ekspresi 'intoleran' di beberapa daerah. Politik identitas yang tumbuh subur di beberapa daerah yang agama menjadi nilai utama kehidupan mereka sehari-hari. Dan, ada banyak perpindahan otoritas keagamaan dari yang semestinya terkultuskan secara sosial dan cultural, ke ruang popularitas serta media sosial.

Kembalinya ruang diskursus keagamaan di Indonesia -menjadi sangat konservatif - ditulis oleh Martin Van Brunessen dengan menyebutkan Indonesia seakan kembali pada carapandang dimasa awal reformasi. Masyarakat mulai kehilangan paham progresifitas untuk 'meninggalkan' agama pada ruang terbuka dan mengedepankan konsolidasi atau integrasi nasional. ${ }^{17}$ Masyarakat Indonesia memiliki kecenderungan untuk meng-ekpresikan agama sebagai sistem sosial dan politik di daerah masing-masing. 18 Padahal riset sebelumnya menyebutkan bahwa komposisi ekpresi keagamaan umat Islam (ataupun Non-Muslim) di Indonesia sudah mengarah dari paradigma konservatif ke arah (personal piety) baik itu yang divisualisasi atau dipraktekkan dalam tradisi sufisme, ekpresi sosial ekonomi dalam bentuk memasukkan akad kepastian sebagai keyakinan sistem ekonomi Islam, dan sosial-politik yang diatur berdasarkan kesepakatan bersama. $^{19}$

Pada era ini pula, relasi antar agama mulai sedikit mengkhawatirkan sebab ekpresi keagamaan acapkali dikapitalisasi sebagai bentuk 'jualan' politik, yang dishare melalui media sosial. Bagi sebagian kalangan fenomena keberagamaan ini sebenarnya tabu, namun sudah menjadi kebiasaan di era revolusi industri hari ini.

17 Oliver Roy, the Failure of Political Islam (Cambridge, Massachusetts: Harvard University Press, 1994), h. 2-4.

18 Martin Van Bruinessen, "Genealogies of Islamic Radicalism in Post-Soeharto Indonesia" dalam South-East Asia Research, Vol 10 No. 2 Tahun 2002, (Singapore: LSAS, 2002), h. 117-123

19 Greg Fealy \& Selly White, Expressing Islam; Religious Life and Politics in Indonesia, (Singapore; ISASS, 2007), h. xx 
Misalnya, beberapa tokoh nasiolan (baca; Presiden dan Tokoh Politik) menyebarkan pelbagai dokumentasi dirinya menjadi jejak digital, lalu dibagikan kepada semua orang. Pada era ini, kesalehan seseorang dalam agama tertentu seakan-akan menjadi instrument invidual yang harus diketahui banyak orang. Maka pada hari ini pula, tidak jarang kita melihat orang yang sedang sholat (baca; beribadah) di media sosial. Orang-orang ini seakan-akan ingin menunjukkan kesalehan kehidupan mereka sehari-hari. Padahal kalau melihat pada era sebelumnya, fenomena dan ekpresi seperti ini menjadi sangat tabu. Tidak banyak orang berhaji yang mempublikasikan perjalana dan cerita hajinya. Kendati penulis juga menyadari bahwa, ciri Revolusi Industri 4.0 adalah menampilkan diri sendiri untuk dilihat secara pribadi ataupun orang lainnya (mirroring their-selves).

\section{Fenomenologi Keberagamaan ala Indonesia}

Jika sebelumnya, penulis hanya melihat ekpresi yang ditampilkan dari sudut pandang yang mengejawantah di lini masa atau diskursus keberagamaan di Indonesia, maka pada pembahasan ini akan lebih banyak membicarakan bagaimana sebenarnya masyarakat Indonesia memahami ekspresi keber-agamaannya. Apakah benar keberagamaan yang terekspresikan dari kesadaran yang dipahami. Atau malah sekedar mengikuti arus sosial, atau mengikuti ajakan yang tersublimasi dibalik ketidaksadaran mereka. Untuk mengulas hal ini, penulis ingin menempatkan beberapa fenomena kekinian bagaimana agama hadir pada ruang kesadaran manusia, melalui tiga sudut pandang; (fundamentalisme, liberalisme, dan moderatisme) sebagai paham yang terekpresi secara antropologis dan sosilogis. Meski sebelumnya penulis ingin memberikan dulu apa yang dimaksud dengan fenomenologi keberagamaan. Douglas Allen, dalam Hinnels, menyatakan bahwa:

"Phenomenology of religion starts with the view that religion is based on religious experience. Human beings have experiences that they describe as religious. These may be traditional or nontraditional. They may focus on inner feelings or outward forms and relations. They may be institutional and involve organized religion, or they may be highly personal and outside of any institutional framework. They may involve prayer, worship, rituals, nature, or cosmic experiences. Human beings 
who reject any personal identification with religion claim that they do not have such religious experiences" 20

Dari kutipan di atas, bisa diartikan bahwa fenomenologi agama memulai berfikir bahwa agama hadir berdasarkan pada pengalaman keberagamaan seseorang. Setiap orang bisa mengekspresikan dirinya sebagai bagian dari agama atau menganggap fenomena tersebut sebagai agama; apakah pada bentuk dan wujud tradisional, institusional, atau relasional. Maka dari itu, seseorang yang tidak mau memahami akan kebiasaan dan dimensi space yang ada di dalam agama, dimungkinkan seseorang itu tidak memiliki pengalaman keberagamaan.

Sependek pengetahuan penulis, bahwa pengalaman keberagamaan fundamentalisme tidak bisa dilepaskan dari tradisi tekstual dalam memahami ajaran agama tersebut. Mereka menutup perluasan makna serta menolak apapun selain apa yang sudah ditentukan di dalam teks agama. Sebaliknya kelompok liberal. Pemahaman mereka lebih bebas, bahkan tidak banyak mengakui keberadaan ajaran agama sebagai guidlines kehidupan sosial. Agama ada di ruang privat yang tidak bisa diintervensi orang lain. Di tengah keduanya ada kelompok moderat yang mengupayakan cara berfikir integratif, sehingga ekpresinya lebih akomudatif terhadap perluasan makna, tanpa harus menghilangkan keyakinan agama sebagai petunjuk kehidupan yang benar. Tiga pengalaman keberagamaan yang terekspresikan tersebut, bersumber dari akulturasi manusia dengan pelbagai kondisi, apakah itu lokal ataupun nasional. Dalam kondisi lokal, maka moderatisme akan lebih disadari sebagai identitas keislaman mereka, Mereka yang terbiasa pada kebudayaan di luar Indonesia akan mengekspresikan sebaliknya. Jadi, ekspresi ini sesederhana yang bisa dilihat dalam kehidupan sehari-hari.

Untuk lebih jelasnya, penulis akan memberikan pemaparan apa saja fenomena-fenomena kekinian dan bagaimana tanggapan para akademisi terkait dengan otoritas keagamaan Islam di Indonesia hari ini.

Pertama, Najib Burhani adalah salah seorang cendikiawan Muslim yang meresahkan fenomena Aksi Bela Islam berepisode di

20 Douglas Allen, "Phenomenology of religion" dalam J. R Hinnels, Rutledge Companion of Religious Study (New York; Routledge, 2005), h. 78 
Pilkada Jakarta Tahun 2017 yang lalu. Menurut dia, jika diruntut bagaimana proses dramatisasi aksi dan demonstrasi tersebut, seakanakan membentuk fragmentasi baru otoritas keagamaan di Indonesia. Buya Syafi'i Ma'arif, Said Aqil Siradj, dan Haedar Nashir, termasuk di panggun politik, seperti Joko Widodo, tidak mampu membendung dan menyerukan agar para pendemo tersebut mengurungkan niatnya. Di akhir tulisannya, dia mempertanyakan apakah kemudian akan nada perubahan otoritas keagamaan, dari yang sudah otoritaif seperti Nahdlatul Ulama' dan Muhammadiya?.21 Kedua, fenomena kesalahan penjelasan ajaran keagamaan dan tulis Arab di sebuah televisi swasta di Indonesia. Fenomena ini memantik Siti Nurul Hidayah untuk mempertanyakan dua hal penting; representasi ulama' (pemegang otoritas keagamaan) yang dihadirkan di televisi dan alasan televisi yang cenderung memikirkan aspek-aspek komersialisme dibandingkan subtansi dari dakwah Islam yang ideal bagi umat Islam. ${ }^{22}$

Ketiga, kembalinya perdebatan terkait siapa sebenarnya yang memiliki hak terhadap otoritas keberagamaan yang ada di Indonesia. ${ }^{23}$ Keempat, meski penulis agak sulit menemukan rujukan pandangan fenomenalnya, ada perdebatan yang selalu ramai dan lama di media sosial, apabila persoalan agama menjadi topik perbincangan mereka. Seakan-akan, jika kita mengamatinya secara seksama, ada ruang deligitimasi oleh pemuka agama yang satu dengan pemuka agama lainnya. Pada bagian keempat ini, bisa saja, diasumsikan bahwa otoritas keagaman Islam pasca kontestasi politik dan aksi bela Islam menghadirkan perubahan audience baik itu pengguna media sosial; ataupun yang hanya melihat pemberitaan di media masa atau televisi. Misalnya, sama seperti apa yang disebutkan oleh Najib Burhani di atas, para netizen cenderung lebih suka mendengarkan dan mengikuti pandangan kelompok-kelompok conservative radikal dibandingkan kelompok

\footnotetext{
${ }^{21}$ Lihat Opini Koran Sindo: Najib Burhani Aksi Bela Islam dan Fragmentasi Otoritas keagamaan:https://nasional.sindonews.com/read/1168539/18/aksi-belaislam-dan-fragmentasi-otoritas- keagamaan-1483668174 (diakses pada tanggal 10 Januari 2018)

22 Lihat Opini Siti Nurul Hidayah "Tele Dai dan Persolan Otoritas Keagamaan" https://news.detik.com/kolom/d-3770783/tele-dai-dan-persoalan-otoritaskeagamaan (diakses pada tanggal 10 Januari 2018)

23 Lihat Artikel terkait media dan otoritas pemikiran Islam pada https:// www.hidayatullah.com/artikel/ghazwul-fikr/read/2017/02/16/111930/sihirmedia-dan-kampanye-anti-otoritas-agama.html (diakses pada tanggal 10 Januari 2018)
} 
moderat. Atau dalam bahasa-bahasa 'me-mey' yang ada di netizen mereka lebih suka yang Islam-nya Kaffah dibandingkan yang setengahsetengah. Atau pula, ada fenomena menarik kala di media sosial ada gambar yang membandingkan keilmuan seorang kyai/ulama' dan ustadz dengan salah seorang Muallaf yang menjadi pendakwah Islam, dst.

Fenomena persegeseran otoritas keagamaan, tampaknya terlatak pada diskursus "how Muslims expressed and considered their religion". Artinya, terkait tentang wacana bagaimana sebenarnya orang-orang Islam mengekpresikan nilai-nilai keberagamaan di ruang publik. Tulisan Siti Nurul Hidayah, bagi penulis, hal ini bukan persoalan kekalahan otoritas para ulama' NU-Muhammadiyah, cendikiawan muslim, dan para otoritarian Islam lain yang lebih memiliki kemampuan untuk memberikan pemahaman kepada umat Islam terkait Islam. Hanya saja, harus diakui, para kyai, ulama' Muhammadiyah, dan cendikiawan Muslim, acapkali mengambil jarak (efek dari kesadaran keagamaan mereka) terhadap hal-hal yang berbau komersial. Dalam pandangan dan kesadaran para kyai misalnya, ekspresi keislaman dan kesadaran keislaman adalah sebuah manifestasi individual, kematangan mental, dan kemampuan untuk memisahkan mana yang termasuk nafsu keduniawian dan keakhiratan. Para kyai ada pada level tidak merasakan kepantasan mengekspresikan keislaman secara berlebihan. Mereka ada pada kadar-kadar bagaimana masyarakat awam tinggal dalam kesederhanaan. Di pihak lain, kelompok intelegensia Muslim pun demikian. Mereka selalu beranggapan ruang 'ceramah agama' (berbasis nilai-nilai keluhuran Islam) bukan bagian ajaran yang diyakini sebagai kebenaran kolektif. Mereka seakan ingin memberikan ruang pembenahan hati umat Islam pada orang-orang yang tidak sekedar 'alim, namun 'abid (ahli beribadah). Oleh karenanya, tidak dapat diherankan jika para pendakwah Islam yang muallaf dan baru belajar agama, memberanikan diri tampil ke ruang publik; karena ketidakpahaman mereka kalau ada konsekwensi duniawi dan ukhrowi disaat membicarakan agama dan mengajak seseorang ke jalur keagamaan.

Fenomena ketiga, persoalan perebutan otoritas di ruang media elektronik dan sosial. Berbeda dengan dua percaturan dan kontestasi sebelumnya yang cenderung melibatkan dualitas aktor dan struktur; ulama' dan organisasi keagamaan, ruang ini lebih pada intersubjektifitas seorang ulama' dan netizen (masyarakat internet). Penulis, 
pada posisi ini, bersepaham dengan Cloete, bahwa udience-lah yang hari ini memiliki otoritsa penuh terhadap nilai-nilai keberagamaan yang dikontestasikan itu. Bukan lagi tokoh, cendikiawan Islam, ulama', ustadz, atau entitas lainnya. Sebab, masyarakat dunia maya ini akan mencari sendiri pandangan hukum, Islam, dan produk pemikiran lainnya, secara acak. Secara subjek- uidence, dia memiliki hak untuk menseleksi mana pandangan yang pantas, dan kemana mereka menyandarkan sikap dan pandangannya sendiri secara bebas dan leluasa. Malahan, tidak jarang terlihat, ketika pemegang otoritas ini sedang berada pada gazwah-firiyyah al diniyah di dunia maya, mereka memilih apatis pada kedua-duanya, lalu keluar dari perdebatan dan mengembalikan pada pengalaman-pengalaman keagamaan yang dilaluinya semasa masih kecil. Jadi, pertarungan di dunia sosial, dalam pandangan penulis, tidak dapat mengkristalisasi sikap keagamaan. Secara fenomenologis, orang yang menghadirkan sikap keagamaan dari dunia maya, akan menghadapi realitas yang ada di depannya. Mereka masih membutuhkan tensi-dialektis antara apa yang mereka baca dan pahami, dengan kondisi sosial dimana mereka hidup.

Persoalan-persoalan otoritas keagamaan yang sudah penulis paparkan, sebenarnya, masih akan menghiasi perdebatan dan perbincangan paham keislaman; apakah itu dari sudut pandang hukum, metodologis, antropologis, sosiologis, dan bahkan fenomenologis. Pada sisi hukum, Wael B. Hallaq sudah memberikan pandangan koherennya bagaimana semestinya persoalan-persoalan interpretasi jurisdistik harus membingkai pandangan hukum Islam; dimulai dari produk ijtihad, madzhad, ber-taqlid, dan melakukan konteks-tualisasi hukum berdasarkan sumber-sumber yang sudah disepakai bersma. ${ }^{24}$ Dalam pandangan yang lebih sederhana, pemegang otorititas keagamaan, seyogyanya memiliki pemahaman holistic bagaimana hukum Islam dilahirkan. Tidak selalu harus menggunakan pandangan individual dan reduktif, laiknya yang trend pada akhir-akhir ini. Semua orang bersepakat bahwa ada prosedur baku dalam mengeluarkan fatwa/produk hukum Islam. Semua orang paham, jawaban hukum Islam harus berlandaskan pada cara berfikir yang runtut, mulai dari pandangan teks, sejarah, hingga konteks yang harus dibedah. Pada masa lalu, para pemegang otoritas keagamaan, secara sadar

24 Wael B. Hallaq, Authority, Continuity, and Change in Islamic Law (London; Cambrige University Press, 2001), h. x 
mempertontonkan itu dengan sangat hati-hati. Mereka yang modernis menulis buku dan gagasan yang dibingkai pada tradisi rasional. Sebaliknya, kelompok tradisional harus membedahnya menggunakan kitab-kitab otoritatif (mu'tabarah), didiskusikan kemudian baru di fatwakan kepada masyarakat. ${ }^{25}$

\section{E. Tantangan dan Pemeliharaan Keberagaman Pada era Revolusi Industri 4.0}

Akhirnya, penulis sampai pada analisis bagaimana memposisikan logos revolusi Industri 4.0 ini sebagai subjek yang bisa merubah ekspresi keagamaan, atau sebaliknya, memaf'ulkan Revolusi Industri 4.0 produk pasif yang membantu dan membentuk ekspresi keagamaan di Indonesia sesuai dengan identitas asalinya. Artinya, keberadaan logos revolusi Industri yang memiliki fitur 'semua digerakkan oleh Internet dan konektivitas virtual' ini bisa memiliki manfaat untuk memperbaiki ekspresi keagamaan yang salah. Serta meminimalisir dampak buruk logos ini, melalui nilai-nilai keagamaan yang diyakini oleh umat beragama di Indonesia. Sebab, pada sisi tertentu dan subtantif, semua agama tidak pernah melarang seseorang untuk melakukan inovasi. Dengan catatan, produk inovatif tersebut memiliki kebermanfaatan yang lebih banyak dibandingkan kemudharatannya.

Bagi penulis, apapun bentuk perkembangan dan inovasi yang akan dihasilkan manusia untuk 'mempermudah' perajalanan hidup melalui ilmu pengetahuan yang dimilikinya, merupakan suatu keniscayaan. Maka dari itu, ekspresi yang merupakan bentuk dari manifestasi pemahaman keagamaan juga tidak bisa dibatasi oleh karena perubahan zaman. Hal yang paling diperlukan hanyalah bagaimana nilai keagamaan dan perubahan sosial dan kemasyarakatan kontra produktif pada nilai kemanfaatan hidup manusia itu sendiri,

25 Jajat Burhanuddin "Traditional Islam and Modernity; Some note Changing of the ulama' in early $20^{\text {th }}$ Century Indonesia " dalam Azyumardi Azra, Kees Van Dijk, dan Nico J.G Kaptein, Varieties of religious Authority; Changes and Challenges in $20^{\text {th }}$ Century Indonesian Islam (Singapore, ISAS Publishing, 2010), h. 69-70, Bandingkan dengan Mutohharun Jinan, "New Media dan Pergeseran Otoritas Keagamaan Islam di Indonesia" dalam Jurnal Lektur Keagamaan, Vol. 10, No. 1, 2012: p. 181 - 208. Lihat tulisan serupa, Mutohharun Jinan "Intervensi New Media dan Impersonalisasi Otoritas Keagamaan di Indonesia" Jurnal Komunikasi Islam Vol 03, Nor 02, Tahun 2013, h. 334335 
sesuai dengan tujuan diciptakannya manusia di dunia. Revolusi Industri 4.0 yang menjadikan ekspresi keberagamaan lebih beragam, futuristik, dan semakin tampak terkontestasi di ruang publik, tidaklah menjadi persoalan yang negatif. Asalkan, sebagaimana yang diulas tadi, tidak ada kesengajaan para ideolog, tokoh, pemuka, dan umat beragama untuk menebar kebencian antar sesama umat beragama. Tampilan agama yang dibungkus dalam produk digital, diinovasi dan dikemas ulang, lalu disebarkan di ruang publik melalui internet, harus tetap menjunjung nilai agama yang subtantif; moderatisme.

Oleh sebab itulah, keberdaan dan kekuatan nilai logos Revolusi Industri 4.0 akan sangat bermanfaat untuk memperkaya 'ajaran' agama, sekaligus model-model transmisinya terhadap masyarakat sekitar, sehingga masyarakat akan lebih mudah untuk memahami agama. Penulis ingin memberikan contoh bagaimana seorang anak bisa belajar sholat hanya melalui play store, membaca al Qur'an menggunakan aplikasi, dan aspek-aspek artificial intelegence lainnya. Jadi, pada posisi ini, inthernet is The Thing, ataupun fitur lainnya merupakan nilai lebih dari manusia untuk memudahkan manusia menjaga kerukunan, ketentaraman, dan nuansa damai antar sesama pemeluk agama. Demikian pula agama Islam yang menjadi agama mayoritas di Indonesia. Keberadaan Produk Revolusi Industri 4.0 juga bukan ancaman, kendati tradisi ini merupakan bentuk dari kebudayaan Barat. Umat Islam seyogyanya mampu mengapresiasi apapun bentuk hasil pengetahuan yang dihasilkan manusia, dengan cara menegasikan agama pencipta tradisi dan keilmuan tersebut, seperti yang ditunjukkan oleh kelompok Islam neo-tradisionalis dan progresif yang ada di Indonesia.

Nilai-nilai kebermanfatan yang menjadi pegangan penulis untuk menilai bahwa revolusi Industri 4.0 bukanlah ancaman terhadap ekspresi keagamaan di Indonesia, akan sedikit berubah apabila melihat bagaimana kelompok-kelompok Islam radikal serta fundamental mengekspresikan paradigma keagamaan mereka. Nuansa segala sesuatu bisa divisualisasi dan dikoneksikan melalui internet menjadikan kekhawatiran berlebih Indonesia akan kembali pada masamasa perjuangan. Masa-masa dimana umat Islam 'memaksakan' kehendak politis mereka menjadi sistem negara, politik, pemerintahan, dan interaksi antar sesama manusia di Indonesia. Kekhawatiran yang demikian memang sangat beralasan. Lebih-lebih kalau semua orang melihat bagaimana ekspresi politik yang dicampur dengan kepentingan 
keberagamaan, seperti yang terjadi di Jakarta tahun 2017, teror kelompok radikal di Surabaya dan sekitarnya, serta kejadian-kejadian lainnya yang dimulai dari pemahaman keagamaan yang salah; pemahaman yang bersumber dari ineternet dan interaksi mereka di media sosial, ceramah agama yang disediakan secara online, tulisan ataupun perangkat internet lainnya.

Dalam konteks ini pula, ekspresi keagamaan yang serba bebas dan sulit dikontrol oleh pemerintah yang menerapkan sistem demokrasi, mewajibkan pemerintah untuk berupaya melakukan counter discourse ditambah kontrol terhadap pemahaman ideologi kebangsaan, dan identitas authentik masyarakat indonesia. Tanpa begitu, pluralitas dan keguyuban umat beragama akan mudah terusik karena ekspresi keagama seorang individu saja. Semua orang pasti ingat bagaimana salah seorang tokoh yang hari ini selalu mengekspresikan paham keagamaannya, sontak menjadikan masyarakat mulai tidak respek terhadap agama lain atau pemeluk keyakinan lainnya. Walaupun, ekspresi tokoh tersebut tidak berbentuk tindakan melainkan melalui media sosial yang dia miliki. Tokoh tersebut pun, seakan-seakan berubah dari politisi menjadi sosok yang sangat paham agama, atau ada yang juga sebaliknya, tokoh agama yang kemudian mengkomunikasiakan atau mengekspresikan pemahaman keagamaannya sehingga menjadi tokoh agama dadakan melalui media sosial.

\section{F. Kesimpulan}

Sebagai penutup pada tulisan ini, penulis ingin memberikan empat kesimpulan penting, sebagaimana kegelisahan yang sudah diungkapkan pada awal tulisan ini. Pertama, secara antropologis, umat beragama di Indonesia, secara garis besar, mengekspresikan keyakinan dan keberagamaan mereka pada ruang-ruang yang proporsional. Artinya, mereka menjaga betul nilai-nilai kebersamaan yang sudah dipraktekkan oleh para pendahulu mereka; baik itu secara adat ataupun agama. Maka dari itu, apapun tantangan yang akan dihadapi, ekspresi otentik ini tidak akan pernah berubah. Kedua, desrupsi ide dan paham keagamaan yang mengjangkiti umat beragama di Indonesia 'melalui media sosial, internet, dan produk digital lainnya' memang mempengaruhi bagaimana umat beragama bersikap. Meskipun tidak sesignifikan mereka yang dijangkiti penyakit indoktrinasi oleh kelompok-kelompok radikal yang ada di Indonesia. 
Ketiga, secara fenomenologis, konstruk kesadaran umat beragama di Indonesia adalah moderat dan toleran. Mereka menghargai perbedaan sebagai hal yang fitrah. Terkecuali, konstruk fenomenologis ini diarahkan atau digeser pada kepentingan politik, sosial, dan kehidupan lain yang ada di masyarakat, sehingga mudah terjadi konflik. Keempat, apapun bentuk revolusi dunia, pemerintah harus selalu hadir sebagai pemfilter dan penyeimbang antara transformasi sosial masyarakat. Pemerintah tidak boleh absen, karena revolusi Industri ini dengan sendirinya aan mempengaruhi model pemerintahan.[]

\section{Daftar Pustaka}

"media dan otoritas pemikiran Islam" https://www.hidayatullah. com/artikel/ghazwulfikr/read/2017/02/16/111930/sihirmedia-dan-kampanye-anti-otoritasagama.html. diakses pada tanggal 10 Januari 2018.

Ahmad Syafi'i Ma'arif, Politik Identitas dan Masa Depan Pluralisme Kita, Jakarta; Democracy Project, 2012.

Akh Muzakki "Fenomena Premanisme Kelompok Keberagamaan dalam perspektif Studi Islam (Makalah seminar "Islam dan Premanisme Kelompok Keberagamaan" oleh Pusat Pengembangan Intelektual (P2I) Program Pascasarjana IAIN Sunan Ampel, di Gedung SAC, IAIN Sunan Ampel, Surabaya, 26 September 2012.

Arie Setyaningrum Pamungkas, "The Dakwah Media in Post Soeharto Indonesia; From Politics Identity to popular culture; The Case of Ummi, Phd Thesis, Universitas Berlin 2015.

Bo Xing \& T Marwala "Implication of the Fourth Industrial Age on Higher Education" dalam Proceedings of the International Joint Conference on Neural Networks, BC, Canada, Maret 2017.

Charlene Tan, Islamic Education andIndoctrination; The Case of Indonesia, New York; Routledge, 2011.

Dale F. Eickelman, "The Study of Islam in Local Context" dalam Richard C. Martin Contribution to Asian Studies, vol. xvii Tahun 1982. 
Douglas Allen, "Phenomenology of religion" dalam J. R Hinnels, Rutledge Companion of Religious Study, New York; Routledge, 2005.

Farish A Noor, Yogindar Sikand, dan Martin Van Bruinessen, ed, The Madrasa in Asia; Political Activism and Transnational Linkage, Amsterdam; Amsterdam University Press, 2008.

Greg Fealy \& Selly White, Expressing Islam; Religious Life and Politics in Indonesia, Singapore; ISASS, 2007.

Greg Fealy dan Anthony Bubalo, Jejak Kafilah, terj. Akh. Muzakki, Bandung; Mizan, 2004.

Husniyatus Salamah "Politic of Cirizenship; Shape of identities, education and critical media literacy" Paper Seminar Internasional Pendidikan Islam di UM Malang Pada Desember 2016; tidak dipublikasikan.

Idrus al-Hamid, "Islam Politik di Papua; Resistensi dan Tantangan Membangun Pedamaian" dalam Jurnal Millah Vol XII, No 02 Tahun 2013.

Jacobus Oosthuizen "The Determinant of Fourth Industrial Revolution Leadership Dexterity; a Poposed Framework for 4IR-Inteligence and Subsequest 4IR Leadership Development" dalam Proceeding of International Conference of Resources Management, Milpark Buiness School.

Jajat Burhanuddin "Traditional Islam and Modernity; Some note Changing of the ulama' in early 20th Century Indonesia " dalam Azyumardi Azra, Kees Van Dijk, dan Nico J.G Kaptein, Varieties of religious Authority; Changes and Challenges in 20th Century Indonesian Islam, Singapore, ISAS Publishing, 2010.

Kim Knot, "Spatial Theory and Method for Study of Religion" dalam The Fenmish Study for the Study of religion, Temenos, Volume 41. No 2, 2005.

Martin Van Bruinessen, "Genealogies of Islamic Radicalism in PostSoeharto

Indonesia" dalam South-East Asia Research, Vol 10 No. 2 Tahun 2002, Singapore: LSAS, 2002. 
Martin Van Bruisennen, "Tradisional and Islamist Pesantrens in Contemporary Indonesia" dalam Fasrish A Noor edt. Madrasa in Asia; Political Activism and Transnational Linkages, Amsterdam; Amsterdam University Press, 2008.

Merlyna Lim, "Radical Islamism in Indonesia and Its Middle Eastern Connection," dalam Meria Journal, Volume 15, Issue 2 June Tahun 2011.

Mutohharun Jinan "Intervensi New Media dan Impersonalisasi Otoritas Keagamaan di Indonesia" Jurnal Komunikasi Islam Vol 03, Nor 02, Tahun 2013.

Mutohharun Jinan, “New Media dan Pergeseran Otoritas Keagamaan Islam Indonesia” dalam Jurnal Lektur Keagamaan, Vol. 10, No. 1, 2012.

Najib Burhani "Aksi Bela Islam dan Fragmentasi Otoritas keagamaan”: https://nasional.sindonews.com/read/1168539/18/aksi-belaislam-danfragmentasi-otoritas-keagamaan-1483668174;

diakses pada tanggal 10 Januari 2018.

Oliver Roy, the Failure of Political Islam, Cambridge, Massachusetts: Harvard

University Press, 1994.

Robert W. Hefner, "Islamic School, Social Movement, and Democracy in Indonesia", dalam Robert W. Hefner edit, Making Modern islam Politic of Education in South Asia, USA: Hawai University Press, 2009.

Roland Berger, "Industry 4.0, The New Industrial Revolution: How Europe Will Succeed, Munich, diakses melalui http://www.rolandberger. com/media/pdf/ pada 12 Juni 2017.

Siti Nurul Hidayah "Tele Dai dan Persolan Otoritas Keagamaan" https://news.detik.com/kolom/d-3770783/tele-dai-danpersoalan-otoritaskeagamaan; diakses pada tanggal 10 Januari 2018.

Siti Qomala Khayati, “Mengantisipsi Lawan Diskursif Islam-Indonesia; bingkai Baru Kelompok Radik menggerogoti Pancasila" dalam Proceeding Annual Confrence of Muslim Scholar, Surabaya 2018. 
Syamsul Rizal, "Media and Islamism in Post New Order Indonesia; The Case of sabili", dalam Jurnal Studia Islamika Vol 12 No 3, Tahun 2005, Jakarta; UIN Syarif Hidayatullah, 2005.

Wael B. Hallaq, Authority, Continuity, and Change in Islamic Law, London; Cambrige University Press, 2001.

Yudi Latief, Geneologi Íntelegensia; Pengetahuan dan Kekuasaan Intelegensia Muslm, Jakarta; Kencana Gramedia Group, 2013.

Zifirdaus Adnan, "Ideological Conflict between the Indonesian Government and the Indonesian Muslim Radical" dalam Australian Folklore: a Yearly Journal of Folklore Studies; February 2017, Australia; Australian Folklore, 2017. 